\section{Type and Rate of Plant Growth Regulator Influence Vegetative, Floral Growth, and Quality of Little Lime ${ }^{\mathrm{TM}}$ Hydrangea}

\author{
Diana R. Cochran and Amy Fulcher ${ }^{1}$
}

ADDITIONAL INDEX wORDs. dikegulac sodium, benzyladenine, ethephon, growth retardant, branch architecture, plant architecture, plant quality

SUMMARY. The objective of these experiments was to evaluate the response of Little Lime $^{\mathrm{TM}}$ hardy hydrangea (Hydrangea paniculata 'Jane') across two seasons in response to single foliar applications of three plant growth regulators (PGRs) at two rates: dikegulac sodium at 800 or $1600 \mathrm{ppm}$, benzyladenine at 300 or $600 \mathrm{ppm}$, or ethephon at 500 or $1000 \mathrm{ppm}$. There were two additional treatments: a handpruned control leaving three nodes and an unpruned water control (untreated) applied the same day as the PGR applications. To evaluate PGR efficacy, vegetative growth, floral attributes, branch symmetry, and phytotoxicity were assessed. Dikegulac sodium significantly increased branch number (BN) compared with all other treatments. Branch symmetry was greater in dikegulac sodium (800 or 1600 ppm) and hand-pruned treatments compared with the untreated and other PGR treatments (2011 and 2012). Flower number was greater in all PGR treatments compared with hand-pruned plants (2011 and 2012). The only treatment that promoted more symmetrical branching without reducing flower count was dikegulac sodium ( 800 or $1600 \mathrm{ppm})$. Phytotoxicity was observed in both seasons; however, no injury symptoms were evident 16 weeks after treatment (WAT), the termination of the experiment.

$\mathrm{W}$ Tithin efficient production systems, ornamental crops need to be uniform in shape and size (Meijón et al., 2009). By regulating plant size and creating a uniform crop, growers can save space during production and transportation and reduce breakage and loss (Hayashi et al., 2001). Controlling plant architecture can also meet the demands of retailers and consumers for more compact, dense (Cameron et al., 2006; Lütken et al., 2012), and symmetrical plants (Glasgow et al., 1998). In addition, growers can manipulate flowering dates to extend shipping periods (Hayashi et al., 2001).

To achieve target uniformity, nursery producers manually prune and, less commonly, use chemical PGRs to enhance plant growth and plant architecture. Manual pruning can be

Department of Plant Sciences, University of Tennessee, Knoxville, TN 37996

We acknowledge Phil Flanagan, Ethan Hagen, Andrea Menendez, Marisol Benitez-Ramirez, Whitney Yeary, and S. Evan Wilson for technical assistance and Harrell's LLC for fertilizer. We thank Dr. Bill Klingeman and Dr. Cheryl Boyer for their critical review of this manuscript before submission.

Mention of a trademark, proprietary product, or vendor does not constitute a guarantee or warrantee of the product and does not imply its approval to the exclusion of other products or vendors that also may be suitable.

${ }^{1}$ Corresponding author. E-mail: afulcher@utk.edu. labor intensive (Banko and Stefani, 1996) and expensive (Holland et al., 2007), yet, may be more environmentally sustainable than chemical control. Although PGRs are generally less labor intensive to apply than manual pruning, they can cause phytotoxicity (Meijón et al., 2009) and be perceived as digressing from sustainable production (Lütken et al., 2012).

Plant growth regulators have several modes of action, including branch inducing, chemical pinching (chemicals that suppress apical dominance), and ethylene generation. Plant responses to PGRs can vary across cultural and environmental conditions. In addition, the rates, timing, and number of applications required to elicit the desired response can vary among plant genera and species (Bruner et al., 2002; Kessler and Keever, 2008). For example, benzyladenine at $300 \mathrm{ppm}$ increased BN in 'Purple Haze' anise hyssop (Agastache), but not in 'Provence' lavender (Lavandula xintermedia) or 'May Night' sage (Salvia Xsylvestris) (Grossman et al., 2012), and $300 \mathrm{ppm}$ benzyladenine and $1000 \mathrm{ppm}$ ethephon increased BN of Marnier's kalanchoe (Kalanchoe marnieriana), but not flower dust plant (K. pumila) (Currey and Erwin, 2012). These differing plant responses validate the importance of optimizing PGR chemistry, as well as rate and application timing based on the target crop, conditions, and desired effect on plant form.

Little Lime ${ }^{T M}$ hydrangea is a new hydrangea cultivar that is increasingly popular, but is not considered attractive in its juvenile plant form because of sparse foliage and limited branching. Since hydrangea species account for an estimated \$73 million in U.S. sales annually [U.S. Department of Agriculture (USDA), 2009], the use of PGRs to control growth could greatly benefit nurseries producing Little $\mathrm{Lime}^{\mathrm{TM}}$. Recently, dikegulac sodium, benzyladenine, and ethephon, all with different modes of action (DNA synthesis inhibitor, branch promoter, and ethylene generator, respectively), have shown success as PGRs on other hydrangea species (Hester et al., 2013), but efficacy on Little Lime $^{\mathrm{TM}}$ is not known. With the variation in plant response, it is recommended to test PGRs on each plant cultivar individually (Currey and Erwin, 2012; Hilgers et al., 2005; Starman et al., 2004). Therefore, the objective of these experiments was to evaluate vegetative and floral development of Little Lime ${ }^{\mathrm{T} M}$ following application of dikegulac sodium, benzyladenine, or ethephon.

\section{Materials and methods}

Two experiments were conducted during Summer/Fall 2011 (2011) and Summer/Fall 2012 (2012). Materials and methods were similar with only differences between dates and the

\begin{tabular}{llll}
\hline $\begin{array}{l}\text { Units } \\
\text { To convert U.S. to SI, } \\
\text { multiply by }\end{array}$ & U.S. unit & SI unit & $\begin{array}{l}\text { To convert SI to U.S., } \\
\text { multiply by }\end{array}$ \\
\hline 3.7854 & gal & $\mathrm{L}$ & 0.2642 \\
2.54 & inch(es) & $\mathrm{cm}$ & 0.3937 \\
6.4516 & inch $^{2}$ & $\mathrm{~cm}^{2}$ & 0.1550 \\
28.3495 & $\mathrm{oz}$ & $\mathrm{g}$ & 0.0353 \\
1 & $\mathrm{ppm}$ & $\mathrm{mg} \cdot \mathrm{L}^{-1}$ & 1 \\
6.8948 & $\mathrm{psi}$ & $\mathrm{kPa}$ & 0.1450
\end{tabular}


number of replications; therefore, materials and methods are described together with differences noted.

Plant material and culture. Little Lime ${ }^{\mathrm{TM}} 2$ 1/4-inch liners (Spring Meadow Nursery, Grand Haven, MI) were potted into 3-gal containers filled with $85 \%$ pine bark and $15 \%$ peat on 24 May 2011 and 8 May 2012. One week after potting (WAP), plants were top dressed with $19 \mathrm{~N}-$ 1.7P-6.6K, 5- to 6-month controlledrelease fertilizer with minors (Harrell's, Lakeland, FL) at $64 \mathrm{~g}$ per container (high label rate). Plants were grown outdoors in full sun at the University of Tennessee, Knoxville (lat. $35.98^{\circ} \mathrm{N}$, long. $83.91^{\circ} \mathrm{W}$, USDA zone $\left.7 \mathrm{a}\right)$. Initial irrigation was applied from a municipal water source for $20 \mathrm{~min}$ at 8:00 $\mathrm{AM}$, and after 6 weeks, irrigation was applied for $15 \mathrm{~min}$, three times per day (8:00 AM, 1:00 PM, and 4:00 PM) every day unless rain occurred, with 3.2-gal/h pressure-compensating spray stakes (PCNL Spray Stake; Netafim, Fresno, CA).

Plant growth regulator application. Three PGRs were applied to Little Lime ${ }^{\mathrm{TM}} 4 \mathrm{WAP}$ (30 June 2011 and 12 June 2012): 800 or 1600 ppm dikegulac sodium (Augeo; OHP, Mainland, PA); 300 or 600 ppm benzyladenine (Configure; Fine Agrochemicals, Walnut Creek, CA); 500 or 1000 ppm ethephon (Florel; Monterey Ag Resources, Fresno, CA). There were two additional treatments: a hand-pruned control leaving three nodes and an unpruned water control (untreated), applied the same day as the PGR applications. All applications were foliarly applied to runoff using a carbon dioxide backpack sprayer (30 psi, TeeJet $8003 \mathrm{E}$ flat fan nozzle; Spraying Systems, Wheaton, IL). At the end of the experiments (16 WAT), vegetative growth $[\mathrm{BN}$, growth index, and leaf index (LI)] and floral attributes (flower number, length, width, and flower index) were recorded. Branch number was determined by counting branches greater than $\mathrm{l}$ inch at the initiation (initial $\mathrm{BN}$ ) and termination (final $\mathrm{BN}$ ) of the experiment. To evaluate PGR effect on branching, branch increase (BI) was determined by subtracting initial $\mathrm{BN}$ from final $\mathrm{BN}$ ( $\mathrm{BI}=$ final $\mathrm{BN}$ - initial BN). Final growth index (FGI) was determined at the termination of the experiment by measuring height, width, and perpendicular width $[$ FGI $=($ height + width + measurements (one leaf per plant) were taken by measuring the length of the midrib and the width at the widest point. These measurements were used in calculating the LI determined using the formula for area of an ellipse $(\mathrm{LI}=$ length of midrib $\times$ width at widest point $\times 0.8$ ). Flower number was recorded at the end of the experiment. One flower per plant was used to determine flower index by first measuring flower length (distance from apex to basal end of panicle) and then flower width (measured at basal end of panicle) to determine flower "half-width" $(0.5 \times$ flower width), and using these measurements in the formula for total surface area of a cone, $\left\{\left(\pi \times\right.\right.$ half-width $\left.^{2}\right)+[(\pi \times$ half-width $) \times \sqrt{ }\left(\right.$ half-width $^{2}+$ height $\left.\left.\left.^{2}\right)\right]\right\}$, to account for the overall shape of the flower. A visual quality rating assessed branch symmetry at the end of the experiments on a $1-7$ scale, where $1=$ significantly worse than untreated, $2=$ moderately worse than untreated, $3=$ slightly worse than untreated, $4=$ no difference from untreated, $5=$ slightly better than untreated, $6=$ moderately better than untreated, $7=$ significantly better than untreated. Plant characteristics contributing to branch symmetry included the extent to which 1) plant architecture appeared symmetrical from all viewpoints, 2) substrate surface was covered by foliage and branches when viewed from overhead, and 3) overall plant architecture was uniformly dense from perpendicular width $) \div 3]$. Leaf

all viewpoints. Plants were evaluated at 2 and 6 WAT for phytotoxicity symptoms on a 0 to 10 visual scale; 0 representing no injury and 10 representing complete kill.

Experimental Design AND ANALYSIs. Experiment was conducted using a completely randomized design with 10 single pot replications (2011) and 16 single pot replications (2012). Data were analyzed using linear models with the GLIMMIX procedure of SAS (version 9.2; SAS Institute, Cary, NC). Treatment differences for vegetative growth and floral attributes were determined using the LSMEANS statement according to the Holm-Simulation method at $\alpha=0.05$. Square root transformations were applied to the branch, flower, and phytotoxicity data for a more normal distribution; however, untransformed data are reported. Branch symmetry was assessed based on the untreated controls; therefore, Dunnett's multiple comparison procedure was used to analyze branch symmetry $(\alpha=0.05)$.

\section{Results}

Foliar sprays containing 800 or 1600 ppm dikegulac sodium increased BN compared with all other treatments in both seasons (Table 1). For example, plants treated with 800 and $1600 \mathrm{ppm}$ dikegulac sodium had 35.8 (163\%) and $27.4(125 \%)$ more branches in 2011 and $23.3(81 \%)$ and $23.5(82 \%)$ more branches in 2012 , compared with hand-pruned plants. However, the lower rates of

Table 1. Final branch number of Little Lime ${ }^{\mathrm{TM}}$ hydrangea and number of branches increased (BI) over the duration of the experiment following a single application of dikegulac sodium, benzyladenine, or ethephon, 16 weeks after treatment ( $n=80$ and 128 in 2011 and 2012, respectively).

\begin{tabular}{|c|c|c|c|c|c|}
\hline \multirow[b]{2}{*}{ Treatment $^{\mathrm{z}}$} & \multirow{2}{*}{$\begin{array}{c}\text { Rate } \\
(\mathrm{ppm})^{\mathrm{y}}\end{array}$} & \multicolumn{2}{|l|}{2011} & \multicolumn{2}{|l|}{2012} \\
\hline & & Branches (no.) ${ }^{x}$ & BI (no.) $)^{\mathrm{w}}$ & Branches (no.) & BI (no.) \\
\hline Dikegulac sodium & 800 & $57.7 \mathrm{a}^{\mathrm{v}}$ & $48.0 \mathrm{a}$ & $52.1 \mathrm{a}$ & $38.6 \mathrm{a}$ \\
\hline Dikegulac sodium & 1600 & $49.3 \mathrm{a}$ & $40.1 \mathrm{a}$ & $52.3 \mathrm{a}$ & $40.2 \mathrm{a}$ \\
\hline Benzyladenine & 300 & $14.4 \mathrm{c}$ & $4.7 \mathrm{bcd}$ & $28.3 \mathrm{~b}$ & $14.5 \mathrm{~b}$ \\
\hline Benzyladenine & 600 & $18.6 \mathrm{bc}$ & $8.7 \mathrm{bc}$ & $27.2 \mathrm{~b}$ & $14.1 \mathrm{~b}$ \\
\hline Ethephon & 500 & $12.5 \mathrm{c}$ & $3.5 \mathrm{~d}$ & $28.7 \mathrm{~b}$ & $15.3 \mathrm{~b}$ \\
\hline Ethephon & 1000 & $16.2 \mathrm{bc}$ & $7.3 \mathrm{bc}$ & $27.9 \mathrm{~b}$ & $13.8 \mathrm{~b}$ \\
\hline Water & - & $13.0 \mathrm{c}$ & $3.7 \mathrm{~cd}$ & $25.9 \mathrm{~b}$ & $12.6 \mathrm{~b}$ \\
\hline Hand-pruned & - & $21.9 \mathrm{~b}$ & $12.7 \mathrm{~b}$ & $28.8 \mathrm{~b}$ & $16.1 \mathrm{~b}$ \\
\hline$P$ value & & $<0.0001$ & $<0.0001$ & $<0.0001$ & $<0.0001$ \\
\hline
\end{tabular}

${ }^{\mathrm{z}}$ Treatments were applied on 30 June 2011 and 12 June 2012.

${ }^{y} 1 \mathrm{ppm}=1 \mathrm{mg} \cdot \mathrm{L}^{-1}$

${ }^{x}$ Final branch number of branches greater than 1 inch $(2.54 \mathrm{~cm})$.

wBranch increase over the experiment $(\mathrm{BI}=$ final branch number - initial branch number $)$.

${ }^{v}$ Means within columns followed by the same letter are not statistically different according to the Holm-Simulation method for mean comparison at $\alpha=0.05$. 
benzyladenine (300 ppm) and ethephon $(500 \mathrm{ppm})$ resulted in $7.5(34 \%)$ and $9.4(43 \%)$ fewer branches than hand-pruned plants in 2011. BI was greatest with dikegulac sodium ( 800 or $1600 \mathrm{ppm}$ ) compared with all other treatments in both seasons.

Branch symmetry, a measure of quality, was affected by treatments (Fig. 1). In 2011, dikegulac sodium $(800$ and $1600 \mathrm{ppm}$ ) and hand-pruned plants had a $1.6(P=0.0054), 1.8(P=$ $0.0026)$, and $1.5(P=0.0203)$ higher branch symmetry rating compared with the untreated plants (4.0), and in 2012 , dikegulac sodium (800 and $1600 \mathrm{ppm}$ ) and hand-pruned plants had a $1.9(P=0.0006), 1.4(P=$ $0.0159)$, and $1.8(P=0.0014)$ higher branch symmetry rating compared with the untreated plants (4.0). By contrast, branch symmetry of hydrangea treated with benzyladenine and ethephon, regardless of rate, did not differ in comparison with the untreated plants in either season.

Hand pruning reduced flower number of Little Lime ${ }^{\mathrm{TM}}$ compared with all other treatments (Table 2). In 2011 , dikegulac sodium at both rates $(800$ or $1600 \mathrm{ppm})$ and the handpruned plants resulted in shorter flowers compared with the untreated, whereas in 2012, the handpruned treatment and only the high rate $(1600 \mathrm{ppm})$ of dikegulac sodium suppressed flower length. Flower width was less in hand-pruned plants compared with all other treatments with the exception of plants treated with $1600 \mathrm{ppm}$ dikegulac sodium in 2011, which had flower widths that were similar to flower sizes on handpruned plants. Flower index was similar among the untreated, dikegulac sodium $(800 \mathrm{ppm})$, benzyladenine (300 or $600 \mathrm{ppm})$, or ethephon (500 or $1000 \mathrm{ppm}$ ) treated plants, whereas flower index of plants treated with dikegulac sodium (1600 ppm) was less than the untreated in 2011. Hand pruning reduced the flower index when compared against flower index of benzyladenine (300 or $600 \mathrm{ppm}$ ), ethephon (500 or $1000 \mathrm{ppm})$, and the untreated plants. In 2012, the untreated and all PGR-treated plants had a greater flower index compared with hand-pruned plants.

In 2011, height of PGR-treated plants was similar to the untreated and hand-pruned (Table 3 ) plants, and in 2012, height was similar

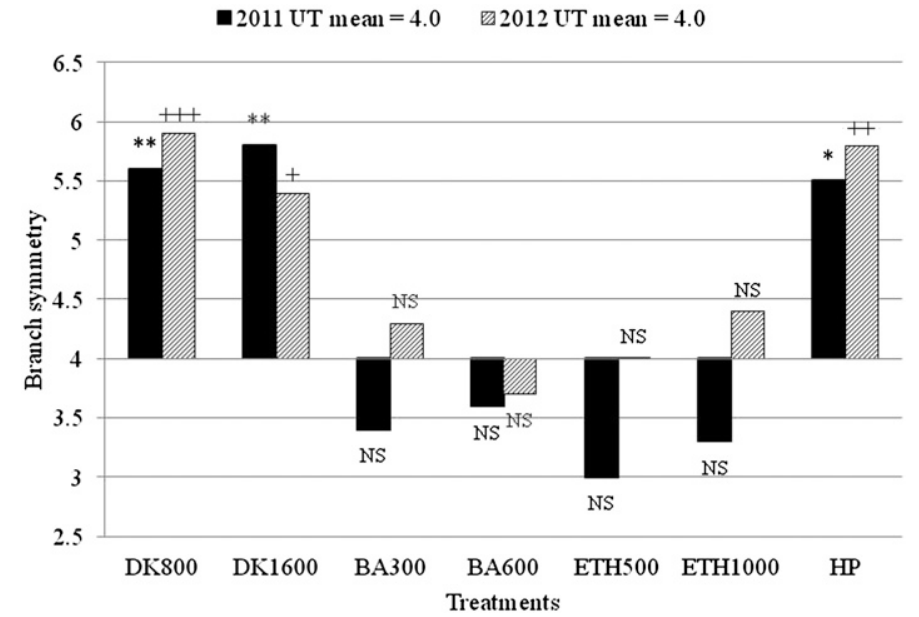

Fig. 1. Branch symmetry of Little Lime ${ }^{\mathrm{TM}}$ hydrangea treated with 800 or $1600 \mathrm{ppm}$ dikegulac sodium (DK800, DK1600), 300 or $600 \mathrm{ppm}$ benzyladenine (BA300, BA600), 500 or 1000 ppm ethephon (ETH500, ETH1000), or hand-pruned (HP) compared with untreated (UT) when applied on 30 June 2011 and 12 June 2012 $\left(1 \mathrm{ppm}=1 \mathrm{mg} \cdot \mathrm{L}^{-1}\right)$. Plants were visually rated on a 1 to 7 scale: $1=$ significantly worse than untreated, 2 = moderately worse than untreated, $3=$ slightly worse than untreated, $4=$ no difference from untreated, $5=$ slightly better than untreated, $6=$ moderately better than untreated, 7 = significantly better than untreated; * * *, NS, significant or nonsignificant based on Dunnett's multiple comparison test at $P \leq$ 0.05 , or $0.01[2011(n=80)] ;^{+},{ }^{++},{ }^{+++},{ }^{\text {NS }}$ significant or nonsignificant based on Dunnett's multiple comparison test at $P \leq 0.05,0.01$, or 0.001 [2012 $(n=128)]$.

Table 2. Flower number, flower length, flower width, and flower index of Little Lime ${ }^{\mathrm{TM}}$ hydrangea following a single application of dikegulac sodium, benzyladenine, or ethephon, 18 weeks after treatment $(n=80$ and 128 in 2011 and 2012, respectively).

\begin{tabular}{|c|c|c|c|c|c|}
\hline Treatment $^{\mathrm{z}}$ & $\begin{array}{c}\text { Rate } \\
(\text { ppm })^{y}\end{array}$ & $\begin{array}{c}\text { Flowers } \\
\text { (no.) }\end{array}$ & $\begin{array}{c}\text { Flower } \\
\text { length }(\mathrm{cm})^{\mathrm{x}}\end{array}$ & $\begin{array}{c}\text { Flower } \\
\text { width }(\mathrm{cm})^{w}\end{array}$ & $\begin{array}{c}\text { Flower } \\
\text { index }\left(\mathrm{cm}^{2}\right)^{\mathrm{v}}\end{array}$ \\
\hline \multicolumn{6}{|l|}{2011} \\
\hline Dikegulac sodium & 800 & $12.5 \mathrm{a}^{\mathrm{u}}$ & $7.3 \mathrm{bcd}$ & $8.5 \mathrm{a}$ & $176.4 \mathrm{abc}$ \\
\hline Dikegulac sodium & 1600 & $8.2 \mathrm{ab}$ & $6.2 \mathrm{~cd}$ & $7.5 \mathrm{ab}$ & $137.8 \mathrm{bc}$ \\
\hline Benzyladenine & 300 & $5.8 \mathrm{ab}$ & $11.5 \mathrm{a}$ & $10.5 \mathrm{a}$ & $325.3 \mathrm{a}$ \\
\hline Benzyladenine & 600 & $6.5 \mathrm{ab}$ & $10.8 \mathrm{ab}$ & $10.0 \mathrm{a}$ & $301.2 \mathrm{ab}$ \\
\hline Ethephon & 500 & $6.6 \mathrm{ab}$ & $10.5 \mathrm{ab}$ & $11.5 \mathrm{a}$ & 320.8 a \\
\hline Ethephon & 1000 & $5.4 \mathrm{~b}$ & $9.9 \mathrm{abc}$ & $10.9 \mathrm{a}$ & $291.0 \mathrm{ab}$ \\
\hline Water & - & $6.6 \mathrm{ab}$ & $11.3 \mathrm{a}$ & $11.7 \mathrm{a}$ & $342.5 \mathrm{a}$ \\
\hline Hand-pruned & - & $1.2 \mathrm{c}$ & $4.1 \mathrm{~d}$ & $4.7 \mathrm{~b}$ & $100.8 \mathrm{c}$ \\
\hline$P$ value & & $<0.0001$ & $<0.0001$ & $<0.0001$ & $<0.0001$ \\
\hline \multicolumn{6}{|l|}{2012} \\
\hline Dikegulac sodium & 800 & $11.3 \mathrm{a}$ & $9.5 \mathrm{ab}$ & $10.2 \mathrm{a}$ & $255.7 \mathrm{a}$ \\
\hline Dikegulac sodium & 1600 & $12.0 \mathrm{ab}$ & $7.6 \mathrm{~b}$ & $9.1 \mathrm{a}$ & $210.4 \mathrm{a}$ \\
\hline Benzyladenine & 300 & $6.4 \mathrm{~b}$ & $10.8 \mathrm{a}$ & $11.6 \mathrm{a}$ & $332.6 \mathrm{a}$ \\
\hline Benzyladenine & 600 & $5.8 \mathrm{~b}$ & $9.9 \mathrm{ab}$ & $10.3 \mathrm{a}$ & $268.5 \mathrm{a}$ \\
\hline Ethephon & 500 & $6.0 \mathrm{ab}$ & $10.0 \mathrm{ab}$ & $10.4 \mathrm{a}$ & $295.6 \mathrm{a}$ \\
\hline Ethephon & 1000 & $5.8 \mathrm{ab}$ & $9.5 \mathrm{ab}$ & $9.9 \mathrm{a}$ & $261.4 \mathrm{a}$ \\
\hline Water & - & $6.4 \mathrm{ab}$ & $10.7 \mathrm{a}$ & $10.9 \mathrm{a}$ & $305.2 \mathrm{a}$ \\
\hline Hand-pruned & - & $1.1 \mathrm{c}$ & $3.3 \mathrm{c}$ & $3.6 \mathrm{~b}$ & $92.7 \mathrm{~b}$ \\
\hline$P$ value & & $<0.0001$ & $<0.0001$ & $<0.0001$ & $<0.0001$ \\
\hline
\end{tabular}

${ }^{\mathrm{z}}$ Treatments were applied on 30 June 2011 and 12 June 2012.

${ }^{\mathrm{y}} 1 \mathrm{ppm}=1 \mathrm{mg} \cdot \mathrm{L}^{-1}$.

xFlower length determined from apical to basal end of panicle; $1 \mathrm{~cm}=0.3937 \mathrm{inch}$

wFlower width determined at basal end of panicle.

${ }^{v}$ Flower index $=\left(\pi \times\right.$ half-width $\left.^{2}\right)+\left[(\pi \times\right.$ half-width $) \times \sqrt{ }\left(\right.$ half-width $^{2}+$ height $\left.\left.^{2}\right)\right]$, where half-width $=0.5 \times$ flower width; $1 \mathrm{~cm}^{2}=0.1550$ inch $^{2}$.

"Means within columns followed by the same letter are not statistically different according to the Holm-Simulation method for mean comparison at $\alpha=0.05$. 
Table 3. Height, final growth index (FGI), and leaf area of Little Lime ${ }^{\mathrm{TM}}$ hydrangea following a single application of dikegulac sodium, benzyladenine, or ethephon, 16 weeks after treatment $(n=80$ and 128 in 2011 and 2012, respectively).

\begin{tabular}{lcccc}
\hline Treatment & $\begin{array}{c}\text { Rate } \\
(\mathbf{p p m})^{\mathbf{y}}\end{array}$ & $\begin{array}{c}\text { Final } \\
\mathbf{h t}(\mathbf{c m})^{\mathbf{y}}\end{array}$ & $\begin{array}{c}\text { FGI } \\
(\mathbf{c m})^{\mathbf{x}}\end{array}$ & $\begin{array}{c}\text { Leaf } \\
\text { index }\left(\mathbf{c m}^{\mathbf{2}}\right)^{\mathbf{w}}\end{array}$ \\
\hline 2011 & & & & \\
Dikegulac sodium & 800 & $39.5 \mathrm{a}^{\mathbf{v}}$ & 46.9 & 4.5 \\
Dikegulac sodium & 1600 & $34.8 \mathrm{ab}$ & 45.1 & 4.5 \\
Benzyladenine & 300 & $37.9 \mathrm{ab}$ & 47.0 & 5.2 \\
Benzyladenine & 600 & $39.5 \mathrm{ab}$ & 49.9 & 5.1 \\
Ethephon & 500 & $31.6 \mathrm{~b}$ & 46.6 & 5.3 \\
Ethephon & 1000 & $33.0 \mathrm{ab}$ & 47.7 & 5.1 \\
Water & - & $38.4 \mathrm{ab}$ & 47.3 & 4.9 \\
Hand-pruned & - & $36.7 \mathrm{ab}$ & 44.3 & 5.5 \\
$P$ value & & 0.0166 & 0.6106 & 0.1525 \\
& & & & \\
2012 & 800 & $33.6 \mathrm{a}$ & $41.7 \mathrm{a}$ & $5.7 \mathrm{abc}$ \\
Dikegulac sodium & 1600 & $31.7 \mathrm{ab}$ & $38.6 \mathrm{ab}$ & $5.3 \mathrm{c}$ \\
Dikegulac sodium & 300 & $31.3 \mathrm{ab}$ & $40.8 \mathrm{ab}$ & $5.8 \mathrm{abc}$ \\
Benzyladenine & 600 & $28.5 \mathrm{bc}$ & $38.7 \mathrm{ab}$ & $5.9 \mathrm{abc}$ \\
Benzyladenine & 500 & $27.8 \mathrm{bc}$ & $37.8 \mathrm{~b}$ & $5.6 \mathrm{bc}$ \\
Ethephon & 1000 & $26.6 \mathrm{c}$ & $37.9 \mathrm{ab}$ & $5.7 \mathrm{abc}$ \\
Ethephon & - & $29.0 \mathrm{~b} \mathrm{c}$ & $37.9 \mathrm{ab}$ & $6.0 \mathrm{ab}$ \\
Water & - & $34.9 \mathrm{a}$ & $40.8 \mathrm{ab}$ & $6.3 \mathrm{a}$ \\
Hand-pruned & $<0.0001$ & 0.0044 & 0.0015 \\
$P$ value & & &
\end{tabular}

${ }^{z}$ Treatments were applied on 30 June 2011 and 12 June 2012.

${ }^{y} 1 \mathrm{ppm}=1 \mathrm{mg} \cdot \mathrm{L}^{-1}, 1 \mathrm{~cm}=0.3937$ inch.

${ }^{x}$ FGI $=($ height + width + perpendicular width $) \div 3$

"Leaf index $=$ length of midrib $\times$ width (measured at widest point of blade) $\times 0.8 ; 1 \mathrm{~cm}^{2}=0.1550 \mathrm{inch}^{2}$.

${ }^{v}$ Means within columns followed by the same letter are not statistically different according to the Holm-Simulation method for mean comparison at $\alpha=0.05$.

among all treatments compared with the untreated plants with the exception of plants treated with dikegulac sodium at $800 \mathrm{ppm}$. Final growth index of PGR-treated plants was similar to untreated and hand-pruned plants in both seasons. Leaf index for PGR-treated plants was similar to the untreated and hand-pruned plants in both seasons with the exception of plants treated with $1600 \mathrm{ppm}$ dikegulac sodium or 500 ppm ethephon, which had a smaller LI in comparison with hand-pruned plants (2012).

In 2011, 2 WAT, phytotoxicity rating of plants treated with dikegulac sodium (800 or $1600 \mathrm{ppm})$ or benzyladenine $(300$ or $600 \mathrm{ppm})$ was greater than the untreated and ethephon-treated plants (Table 4). Symptoms were more pronounced on new growth with complete bleaching of the first, second, and, sometimes, third distal sets of leaves, and interveinal chlorosis on the following one to two sets of leaves. Lower foliage on hand-pruned plants was scorched substantially following pruning. Although this was irradiation damage and not a toxic response to an application, it was the direct result of the hand-pruned treatment and therefore was treated as phytotoxicity. At 6 WAT, there were no differences among treatments as previously chlorotic leaves regained a normal, green appearance. In 2012, at 2 and 6 WAT, plants treated with 800 or 1600 ppm dikegulac sodium had higher phytotoxicity ratings than all other treatments.

\section{Discussion}

Dikegulac sodium-treated plants ( 800 or $1600 \mathrm{ppm}$ ) had more branches compared with all other treatments, including the hand-pruned plants. Moreover, plants treated with dikegulac sodium developed at least $101 \%$ more branches than the untreated plants. These results are similar to that of Hester et al. (2013) that showed more branching in 'Limelight' hardy hydrangea $(H$. paniculata $)$ treated with dikegulac sodium (800 or $1600 \mathrm{ppm})$ compared with the hand-pruned control treatments. By the end of the experiment (16 WAT), benzyladenine $(600 \mathrm{ppm})$ and ethephon (500 or
$1000 \mathrm{ppm})$ suppressed plant height compared with hand-pruned plants (2012), but neither PGR affected branching. Conversely, dikegulac sodium, which functions as a chemical pincher, did not suppress height, but increased number of branches compared with all other treatments. Holland et al. (2007) reported similar results with cyclanilide, another chemical pincher increasing lateral growth but not affecting height of 'Ellen Huff' oakleaf hydrangea ( $H$. quercifolia). There was no change in height or increase in $\mathrm{BN}$ of plants treated with 300 ppm benzyladenine compared with hand-pruned plants, which suggests 300 ppm benzyladenine may not be a sufficient rate or Little Lime ${ }^{\mathrm{TM}}$ needs multiple applications. Grossman et al. (2012) reported increased branching following benzyladenine application in only two of the five herbaceous ornamental plant species they evaluated. Variation in response has been attributed to rapid metabolization of benzyladenine by some plant species and a consequent need for higher rates or multiple applications (Carey et al., 2009; Moffatt et al., 1991).

Hand pruning also results in removal of flower buds and flower primordia, which became evident in these experiments wherein handpruned plants produced at least $78 \%$ fewer flowers than all other treatments. In 2011, plants treated with 800 or 1600 ppm dikegulac sodium had shorter flowers than that observed on untreated plants, whereas neither benzyladenine nor ethephon reduced flower size compared with the untreated. This was similar to results with growth retardants; uniconazole reduced flower diameter of 'Böttstein' bigleaf hydrangea (H. macrophylla), whereas a single application of daminozide or paclobutrazol had no effect on flower diameter (Bailey and Clark, 1992).

Two major disadvantages limiting widespread PGR adoption by growers are the likelihood of phytotoxicity among treated plants and the tremendous variation in plant species responses to PGR chemistries and rates. For instance, Currey and Erwin (2012) reported phytotoxicity on chandelier plant ( $K$. manginii), one of 11 Kalanchoe spp. evaluated following $1000 \mathrm{ppm}$ ethephon (applied 2 weeks after pinching), but no injury following benzyladenine 
Table 4. Visual assessment of Little Lime ${ }^{\mathrm{TM}}$ hydrangea following a single application of dikegulac sodium, benzyladenine, or ethephon $(n=80$ and 128 in 2011 and 2012, respectively).

\begin{tabular}{lccc}
\hline & $\begin{array}{c}\text { Rate } \\
(\mathbf{p p m})^{\mathrm{y}}\end{array}$ & \multicolumn{2}{c}{ Phytotoxicity $(\mathbf{0}-\mathbf{1 0} \text { scale })^{\mathrm{x}}$} \\
\cline { 4 - 4 } Treatment & 2 WAT & 6 WAT \\
\hline 2011 & & & \\
Dikegulac sodium & 800 & $3.7 \mathrm{a}^{\mathrm{w}}$ & 3.0 \\
Dikegulac sodium & 1600 & $4.0 \mathrm{a}$ & 3.2 \\
Benzyladenine & 300 & $3.0 \mathrm{a}$ & 2.7 \\
Benzyladenine & 600 & $3.1 \mathrm{a}$ & 1.7 \\
Ethephon & 500 & $0.7 \mathrm{c}$ & 1.5 \\
Ethephon & 1000 & $1.3 \mathrm{c}$ & 2.9 \\
Water & - & $1.5 \mathrm{bc}$ & 1.4 \\
Hand-pruned & - & $3.1 \mathrm{ab}$ & 1.9 \\
Pvalue & & & 0.0747 \\
& & & \\
2012 & 800 & $2.3 \mathrm{a}$ & $4.6 \mathrm{a}$ \\
Dikegulac sodium & 1600 & $2.7 \mathrm{a}$ & $4.1 \mathrm{a}$ \\
Dikegulac sodium & 300 & $0.0 \mathrm{~b}$ & $0.7 \mathrm{~b}$ \\
Benzyladenine & 600 & $0.0 \mathrm{~b}$ & $0.8 \mathrm{~b}$ \\
Benzyladenine & 500 & $0.0 \mathrm{~b}$ & $1.0 \mathrm{~b}$ \\
Ethephon & 1000 & $0.0 \mathrm{~b}$ & $1.0 \mathrm{~b}$ \\
Ethephon & - & $0.0 \mathrm{~b}$ & $0.8 \mathrm{~b}$ \\
Water & - & $0.3 \mathrm{~b}$ & $1.1 \mathrm{~b}$ \\
Hand-pruned & & $<0.0001$ & $<0001$ \\
$P$ value & & &
\end{tabular}

${ }^{2}$ Treatments were applied on 30 June 2011 and 12 June 2012.

${ }^{y} \mathrm{lppm}=1 \mathrm{mg} \cdot \mathrm{L}^{-1}$

${ }^{x}$ Assessed 2 and 6 weeks after treatment on a $0-10$ visual scale $(0=$ no injury, $10=$ complete kill $)$.

"Means within columns followed by the same letter are not statistically different according to the Holm-Simulation method for mean comparisons at $\alpha=0.05$

exposure; whereas Farris et al. (2009) reported injury to 'Moonbeam' tickseed (Coreopsis verticillata) following application of 250 and 500 ppm benzyladenine. In addition, Banko and Stefani (1996) reported chlorosis on 'Convexa' holly (Ilex crenata) but not on 'Hetzi' juniper (Juniperus chinensis) or 'Manhattan' euonymus (Euonymus kiautschovicus) after dikegulac sodium application. These options may still be viable for saving labor in production systems if the focus on use can be adjusted to whether plants can quickly overcome the injury before point-of-sale. For example, in our experiment, phytotoxicity was visible 6 WAT in 2012, but it was not detected at the end of the experiment (16 WAT). Since 16 weeks is a practical growing duration for hydrangea species under typical production constraints, these early symptoms of foliar phytotoxicity would typically not prevent the plants from being sold.

Marketing surveys have shown that retail, and even wholesale, customers prefer to buy symmetrical plants with dense, compact foliage (Glasgow et al., 1998; Jeffers et al.,
2009; Townsley-Brascamp and Marr, 1995). By using PGRs to break apical dominance, growers can produce fuller, more compact plants (Grossman et al., 2012), thus improving overall plant quality (Hammond et al., 2007). Our experiments support this with treatments of dikegulac sodium increasing $\mathrm{BN}$ and improving branch symmetry by at least $35 \%$ compared with the untreated plants.

Hand pruning did not appear to be an effective tool that growers should rely on either to increase BN or reduce the size of Little Lime ${ }^{T M}$. Moreover, hand pruning excised floral buds and flower primordia on hydrangea, which is a major attribute to the marketability of Little Lime ${ }^{\mathrm{TM}}$. Although neither benzyladendine nor ethephon did not diminish vegetative or floral development of Little Lime ${ }^{\mathrm{TM}}$ compared with the untreated plants, there was also no added advantage to investing in that management action. In conclusion, although some temporary foliar phytotoxicity was observed early in 2012, dikegulac sodium appears to be a good choice for increasing $\mathrm{BN}$ and branch symmetry.

\section{Literature cited}

Bailey, D.A. and B. Clark. 1992. Summer applications of plant growth retardants affect spring forcing hydrangeas. HortTechnology 2:213-216.

Banko, T.J. and M.A. Stefani. 1996. Growth response of large, established shrubs to Cutless, Atrimmec, and Trimcut. J. Environ. Hort. 14:177-181.

Bruner, L.L., G.J. Keever, J.R. Kessler, and C.H. Gilliam. 2002. Atrimmec suppresses shoot length and promotes branching of Lonicera $\times$ heckrottii 'Goldflame' (Goldflame honeysuckle). J. Environ. Hort. 20:73-76.

Cameron, R.W.F., R.S. Harrison-Murray, C.J. Atkinson, and H.L. Judd. 2006. Regulated deficit irrigation-a means to control growth in woody ornamentals. J. Hort. Sci. Biotechnol. 81:435443.

Carey, D., W. Buhler, and B. Whipker. 2009. Stimulating plant growth. Greenhouse Prod. News 9:20-24.

Currey, C.J. and J.E. Erwin. 2012. Foliar applications of plant growth regulators affect stem elongation and branching of 11 kalanchoe species. HortTechnology 22:338-344.

Farris, M.E., G.J. Keever, J.R. Kessler, and J.W. Olive. 2009. Benzyladenine and cyclanilide promote shoot development and flowering of 'Moonbeam' coreopsis. J. Environ. Hort. 27:176182.

Glasgow, T.E., T.E. Bilderback, T. Johnson, K.B. Perry, and C.D. Safley. 1998. Evaluating consumer perceptions of plant quality. Proc. Southern Nursery Assn. Res. Conf. 43:497-500.

Grossman, M., J. Freeborn, H. Scoggins, and J. Latimer. 2012. Benzyladenine increases branching but reduces root growth of herbaceous perennial liners. HortScience 47:1085-1090.

Hammond, H.E., R.K. Schoellhorn, S.B. Wilson, and J.G. Norcini. 2007. Differing blanketflower cultivar and ecotype responses to plant growth regulators. HortTechnology 17:552-556.

Hayashi, T., R.D. Heins, A.C. Cameron, and W.H. Carlson. 2001. Ethephon influences flowering, height, and branching of several herbaceous perennials. Scientia Hort. 91:305-323.

Hester, K.A., G. Bi, M.A. Czarnota, A. Fulcher, G.J. Keever, J.H. Lieth, J.D. Orsi, B.E. Whipker, K. Sullivan, and C.L. Palmer. 2013. Impact of Augeo, Configure and Florel on hydrangea branching. J. Environ. Hort. 31:27-29. 
Hilgers, K.R., C. Haynes, and W.R. Graves. 2005. Chemical height control of containerized seashore mallow. HortTechnology 15:330-332.

Holland, A.S., G.J. Keever, J.R. Kessler, and F. Dane. 2007. Single cyclanilide applications promote branching of woody ornamentals. J. Environ. Hort. 25:139-144.

Jeffers, A.H., M.A. Palma, W.E. Klingeman, C.R. Hall, D.S. Buckley, and D.A. Kopsell. 2009. Assessments of bare-root liner quality and purchasing decisions made by green industry professionals. HortScience 44: 717-724.

Kessler, J.R. and G.J. Keever. 2008.

Plant growth retardants affect growth and flowering of Achillea × 'Coronation Gold'. J. Environ. Hort. 26:24-28.

Lütken, H., J.L. Clarke, and R. Müller. 2012. Genetic engineering and sustainable production of ornamentals: Current status and future directions. Plant Cell Rpt. 31:1141-1157.

Meijón, M., R. Rodríquez, M. Cañal, and I. Feito. 2009. Improvement of compactness and floral quality in azalea by means of application of plant growth regulators. Scientia Hort. 119:169-175.

Moffatt, B., C. Pethe, and M. Laloue. 1991. Metabolism of benzyladenine is impaired in a mutant of Arabidopsis thaliana lacking adenine phosphoribosyltransferase activity. Plant Physiol. 95:900-908.

Starman, T.W., M.C. Robinson, and K.L. Eixmann. 2004. Efficacy of ethephon on vegetative annuals. HortTechnology 14:83-87.

Townsley-Brascamp, W. and N.E. Marr. 1995. Evaluation and analysis of consumer preferences for outdoor ornamental plants. Acta Hort. 391:199-206.

U.S. Department of Agriculture. 2009. 2009 Census of horticultural specialties. 5 Jan. 2013. <http://www.agcensus. usda.gov/Publications/2007/Online_ Highlights/Census_of_Horticulture_ Specialties/hortic_1_023_023.pdf>. 